\title{
Економічна оцінка Черемського болота на основі екосистемних послуг
}

\author{
Валентина Андреєва', Василь Войтюк'1, Олександр Кичилюк'1, \\ Марія Шепелюк'1, Анатолій Гетьманчук'1, Віталій Деркач² \\ 1 Волинський національний університет імені Лесі Українки, Луцьк, Україна \\ 2 Ківерцівський національний природний парк «Цуманська пуща», Ківерці, Україна
}

Адреса для листування: AndreevaValentyna@vnu.edu.ua

Отримано: 17.02.21; прийнято до друку: 15.06.21; опубліковано: 02.09.21

Резюме. Унікальністю Черемського природного заповідника $є$ не тільки збереження рідкісних і типових природних комплексів Українського Полісся, але й те, що його територія входить до складу водно-болотного угіддя міжнародного значення «Заплава р. Стоходу», яке, згідно з критеріями Рамсарської конвенції, має велику цінність. Оскільки із загальної площі Черемського природного заповідника болота займають $33,7 \%$ території, актуальним є вивчення їх екосистемного значення.

Методика інтегральної вартісної оцінки екосистемних послуг базується на теорії екологічної ренти і механізмі ії̈ вираження - альтернативної вартості з урахуванням ефективності відтворення в економічній та екологічній сферах. Поелементна вартісна оцінка екосистемних послуг заснована на оцінці величини депонування вуглекислоти лісовими й природними болотними екологічними системами, сорбційної функції боліт, асиміляційного потенціалу лісових екологічних систем. Представлені результати апробації методики вартісної оцінки екосистемних послуг Черемського болота у Черемському природному заповіднику.

Показано, що Черемське болото забезпечує виконання екосистемних послуг на суму 3696003 грн/рік, а також сорбційну (водоочисну) функцію на суму 11560951 грн/рік та поглинання діоксиду вуглецю на суму 244048 грн/рік.

Ключові слова: перехідне болото, екосистемні послуги, Черемський природний заповідник.

\section{Economic estimation of Cheremsky swamp on the basis of ecosystem services}

\author{
Valentyna Andreieva ${ }^{1}$, Vasyl Voitiuk' ${ }^{1}$, Oleksandr Kychyliuk' ${ }^{1}$, \\ Mariia Shepeliuk', Anatolii Hetmanchuk', Vitalii Derkach² \\ 1 Lesia Ukrainka Volyn National University, Lutsk, Ukraine \\ 2 Kivertsy National Nature Park "Tsumanska Pushcha", Kivertsy, Ukraine \\ Correspondence: AndreevaValentyna@vnu.edu.ua
}




\begin{abstract}
The uniqueness of Cheremsky Nature Reserve is not only the preservation of rare and typical natural complexes of Ukrainian Polissya, but also the fact that its territory is part of the wetland of international importance "Flood of the Stokhod River", which, according to the Ramsar Convention, is of great value. Since of the total area of the Cheremsky Nature Reserve, swamps occupy $33.7 \%$ of the territory, it is important to study their ecosystem significance. The method of integrated valuation of ecosystem services is based on the theory of ecological rent and the mechanism of its expression - alternative value, taking into account the efficiency of reproduction in the economic and ecological spheres. Element-by-element cost assessment of ecosystem services is based on the assessment of the amount of carbon dioxide deposition by forest and natural wetland ecological systems, the sorption function of wetlands, the assimilation potential of forest ecological systems. The results of approbation of the method of cost estimation of ecosystem services of Cheremsky bog in Cheremsky nature reserve are presented. It is shown that Cheremsky bog provides ecosystem services in the amount of UAH 3696003 / year, as well as sorption (water treatment) function in the amount of UAH 11560951 / year and carbon dioxide absorption in the amount of UAH 244048 / year.
\end{abstract}

Keywords: transitional bog, ecosystem services, Cheremsky nature reserve.

\section{ВСТУП}

Економічна оцінка природних ресурсів - це визначення цінності джерел природних ресурсів у грошовому виразі. У філософсському розумінні поняття оцінка $є$ категорією проблеми цінності [3]. Цінність відображає реальні взаємовідносини людини з явищами навколишнього світу. Вона не повинна ототожнюватися 3 самим об'єктом, а має відображати його значення та властивість задовольняти потреби людини. А отже, потреба людей $є$ суб'єктивним фрактором цінності. Об'єктивна сторона цінності визначається реальними властивостями об'єкта оцінки як носія цінності. Звідси випливає, що об'єктом оцінки $є$ не ліс чи земля, як вид природних ресурсів, а їх властивості задовольняти потреби суспільства. Питання економічної оцінки природних ресурсів на основі її екосистемних послуг грунтовно досліджено у працях як українських, так і зарубіжних учених, зокрема І. Лицура, А. Неверова та ін. $[4 ; 6]$.

Згідно з А. В. Неверовим та О. А. Варапаєвою [5], основною проблемою відтворення екологічних ресурсів (екосистемної продукції та екосистемних послуг) $€$ недооцінка їх економічної цінності, зумовлена методологічним безсиллям перед вартісною оцінкою колосальної складності природи, її функцій і взаємозв'язків. Одночасно неконструктивну роль можуть відіграти різного роду оцінки, які абсолютизують економічну цінність природи, виводячи її за реальні вартісні відносини.

\section{МАТЕРІАЛИ ТА МЕТОДИ ДОСЛІДЖЕНЬ}

Черемський природний заповідник (далі Черемський ПЗ) площею 2975,7 га створений 19 грудня 2001 р. і знаходиться у північній частині Маневицького району Волинської області на межі з Рівненською областю. Його територія простягається суцільним лісо-болотним масивом із півночі на південь на 7 км, із заходу на схід - на 8 км [7].

Гідросітку поверхневих вод Черемського ПЗ і прилеглих до його територій утворюють болота, озера, канали та струмки, річка Веселуха (яка протікає за 1,5-2 км на схід від заповідника). У східній частині Черемського болотного масиву проходить, погано виражена, лінія вододілу басейнів річок Стохід і Веселуха басейну ріки Дніпро.

Вартісна оцінка екосистемних послуг і біологічного різноманіття Черемського болота проводилась за методикою А. В. Неверова [6].

Залежно від цілей вартісної оцінки та сфрери застосування результатів використовуються такі ії види:

- інтегральна вартісна оцінка екосистемних послуг (IBOEП) і вартісної цінності біорізноманіття застосовується для обґрунтування альтернативних варіантів їх використання;

- поелементна вартісна оцінка (ПВОЕП) використовується в прикладних дослідженнях, пов'язаних із урахуванням цінності конкретних соціально значущих нетоварних екосистемних послуг, а також для порівняння з проведеними на міжнародному рівні оцінками. 
IBOEП базується на теорії екологічної ренти і механізмі її вираження - альтернативної вартості з урахуванням ефективності відтворення в економічній та екологічній сферах.

ПВОЕП заснована на оцінці величини депонування двоокису вуглецю лісовими та болотними екологічними системами, сорбційної (водоочисної) функції боліт, асиміляційного потенціалу лісових екологічних систем.

Інтегральна вартісна оцінка екосистемних послуг (Цеп) визначалася за формулою:

$$
\bigsqcup_{\mathrm{eп}}=\sum_{l} R_{\mathrm{e \kappa l}} \times S_{l}(1),
$$

де $R_{\text {ekl }}$ - поточна (щорічна) оцінка послуг екологічної системи l-го типу, грн/га;

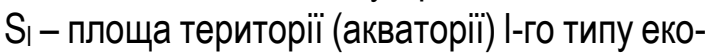
логічної системи, га.

Розрахунок щорічної IBOEП проводиться за чотирма основними типами природних екологічних систем: лісовим, луговим, природним болотним і водним за формулою:

$$
R_{e k_{l}}=\left(R_{l} \frac{q_{e}}{q_{e 1}}-R_{l}\right)=R_{l}\left(\frac{q_{e}}{q_{e 1}}-1\right)(2),
$$

де $\mathrm{R}_{\mathrm{I}}$ - питома поточна (щорічна) оцінка (диференціальна рента) для І-го типу екологічної системи, грн/ га; qе - капіталізатор економічної сфери (прийнятий на рівні 0,05 ); $q_{e l}$ - капіталізатор, значення якого обернено пропорційне терміну відтворення споживаної природної речовини, що складає основу природної екосистеми I-го типу.

Якщо спостерігається поєднання екосистем, наприклад, ліс, що росте на болоті, оцінка проводиться для кожної екосистеми і підсумовуєтьСя.

Розрахунок поточної (щорічної) оцінки $\mathrm{R}_{\mathrm{I}}$ для лісових екосистем здійснюється за формулою

$$
R_{l}=\frac{Ц \times K_{R}}{1+p+K_{R}} \times K_{\text {вих }} \times K_{\text {гцп }} \times K_{\text {пп }} \times K_{\mathrm{E}} \times P(3),
$$

де Ц - ринкова ціна основного продукту природокористування (за пиломатеріалами хвойних порід), грн/м3; p - коефіцієнт ефективності (рентабельності) виробництва продукції в результаті експлуатації основного продукту природокористування $(0,3)$; К $K_{R}$ коефріцієнт ефективності відтворення основного продукту природо- користування $(0,3) ; К_{\text {гцп }}$ коефіцієнт господарської цінності головної деревної породи на оцінюваній ділянці; К Кп - коефіцієнт, що відображає вартість продукції побічного лісокористування

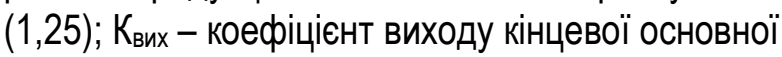
продукції природокористування з одиниці природної сировини $(0,7) ; K_{\mathrm{E}}$ - коефріцієнт екологічної значимості лісових екологічних систем встановлюється для рідкісних лісових біотопів (2); Р щорічна продуктивність ресурсу основного продукту природокористування в розрахунку на 1 га площі, м3/га / рік.

Використовуючи аналогічну схему розрахунку, можна визначити поточні щорічні оцінки і для інших типів екосистем: водних, лугових, болотних, коректуючи формулу (2) з урахуванням специфіки конкретної екосистеми. В якості ціни кінцевого продукту природокористування при проведенні таких оцінок прийняті відповідно ціни на прісну питну воду, сіно, торф паливний.

Розрахунок поточної (щорічної) оцінки $\mathrm{R}_{\mathrm{I}}$ для болотних екосистем здійснюється за формулою:

$$
\begin{gathered}
R_{l}=\frac{Ц \times K_{R}}{1+p+K_{R}} \times K_{\text {вих }} \times K_{\mathrm{CO} 2} \times K_{\phi} \times K_{\mathrm{E}} \times \\
3_{\text {ап }} \times q_{\mathrm{e \kappa} l}(4),
\end{gathered}
$$

де Ц - середня ринкова ціна основного продукту природокористування на момент оцінки (по торфу паливному 36 євро за тонну, торф фррезерний для сільського господарства 200400 грн/т), грн/т;

p - коефріцієнт ефрективності (рентабельності) виробництва продукції в результаті експлуатації основного продукту природокористування $(0,3)$;

$K_{R}$ - коефріцієнт ефективності відтворення основного продукту природокористування $(0,3)$;

$\mathrm{K}_{\text {вих }}$ - коефріцієнт виходу господарської продукції з одиниці природної сировини, який враховує технологічні втрати при сушці, транспортуванні $(0,6)$;

Ксо2 - коефіцієнт, що відповідає питомому показнику щорічного поглинання діоксиду вуглецю природною болотною екологічною системою залежно від типу торфу в розрахунку на 1 га болота;

$К_{ф}$ - коефіцієнт, що диференціює водоочисну здатність болота, в розрахунку на 1 га болота; 
$\mathrm{K}_{\mathrm{E}}$ - коефріцієнт екологічної значимості природних болотних екологічних систем (встановлюється для рідкісних біотопів боліт), для інших болотних біотопів встановлюється Ке = 1 ;

$3_{\text {ап }}$ питомий запас торфу у покладіт/га;

qекі - капіталізатор, або коефріцієнт дисконтування, значення якого обернено пропорційне терміну відтворення споживаної природної речовини, що становить основу природної екологічної системи I-го типу $(0,001)$ [2].

Порядок проведення поелементної вартісної оцінки екосистемних послуг включає визначення: вартісної оцінки вуглецеводепонуючої здатності лісових і болотних екологічних систем (ВОВД), вартісної оцінки сорбційної (фрільтраційної, водоочисної) функції боліт (ВОСФ) і оцінки асиміляційного потенціалу лісових екологічних систем (АПЛЕ).

ВОВД для лісових і болотних екологічних систем визначається як вартісна оцінка щорічного поглинання діоксиду вуглецю лісовими й болотними екосистемами (Опит, грн) за формулою

$$
\mathrm{O}_{\text {пит }}=Ц_{\mathrm{CO}_{2}} \times \mathrm{A}(5)
$$

де A - акумуляція діоксиду вуглецю $\left(\mathrm{CO}_{2}\right)$ лісовою екологічною системою, т / рік; Цсо2 - середня світова ціна квоти на викид 1 т $\mathrm{CO}_{2}$, грн.

Вартісна оцінка сорбційної функції боліт (ВОСФ) визначається як вартість їх використання по природному очищенні води (О фільтр) за формулою

$$
\mathrm{O}_{\text {фільтр }}=\mathrm{O}_{\text {пром }} \frac{\sum s_{i} \lambda_{\text {прир }}}{\lambda_{\text {пром }}}(6)
$$

де Опром - річна приведена вартість промислової очисної установки, грн;

i = 1, 2, 3 - тип торфу в покладі;

$\mathrm{S}_{\mathrm{i}}$ - площа відповідного типу торф'яного покладу, га;

$\lambda_{\text {пром }}$ - фільтруюча здатність промислової установки м $3 /$ добу;

$\lambda_{\text {прир }}$ - фільтруюча здатність і-того виду боліт, м3/добу на га, приймаємо відповідно до [10].

Економічна оцінка первинної продукції (екологічної системи) визначається через вартісне вираження експлуатаційної цінності екологічної системи, розрахованої на базі капіталізованої величини диференціальної ренти:

$$
\mathrm{O}_{\text {екос }}=\sum_{l} \frac{R_{l}}{q_{e k l}} \times S_{l}(7)
$$

де Оекос - економічна оцінка первинної продукції (екологічної системи), грн; $\mathrm{R}_{\mathrm{l}}$ - питома поточна (щорічна) оцінка (диференціальна рента) для І-го типу екологічної системи, грн/га; qекl - капіталізатор, значення якого обернено пропорційне терміну відновлення споживаної природної речовини, що становить основу природної екологічної системи I-го типу; $S_{\text {I }}$ - площа території (акваторії) І-го типу екологічної системи, га.

Екологічна оцінка водоочисної функції болотних екосистем визначається за їх фільтраційною здатністю, яка прирівнюється до фільтраційної здатності промислової очисної споруди з пропускною здатністю 1500 м³/добу, ціна якої досягає в середньому 50 тисяч доларів, а термін експлуатації не менше 50 років.

Низинні болота порівняно з іншими типами боліт мають мінімальну пропускну здатність $137 \mathrm{~m} 3 /$ добу, тобто 11 га болота очищає стічні води еквівалентно одній промисловій очисній установці [9]. Верхові болота мають пропускну здатність 685 м³/добу, тобто 2 га верхового болота очищає стічні води еквівалентно одній промисловій очисній установці [7].

\section{РЕЗУЛЬТАТИ Й ОБГОВОРЕННЯ}

Економічна оцінка депонуючої функції болотних екосистем визначається за об'ємом стоків $\mathrm{CO}_{2}$ і має особливе значення у зв'язку з фрормуванням глобального ринку торгівлі вуглецевими квотами. Враховуючи, що балансовий річний стік $\mathrm{CO}_{2}$ в природні болотні екосистеми верхового типу складає 0,88-2,15 т/га, для низинного 0,561,04 т/га (Н. Н. Бабалов, В. А. Ракович, 2005; цит. за [10]), болота Черемського природного заповідника щорічно депонують $\mathrm{CO}_{2}$ від 1007,6 до 1908 т. Для порівняння чисте поглинання вуглецю лісами України в середньому 1,4-2,0 тонни на гектарі за рік, що в перерахунку на вуглекислий газ складає 5-7,3 тонн [9].

Мінімальна вартість однієї тонни $\mathrm{CO}_{2}$-еквівалента на світовому ринку складає 5 доларів за тонну [10].

Вартісна оцінка щорічного поглинання діоксиду вуглецю болотними екосистемами при середній європейській ціні квоти на викид 1 т $\mathrm{CO}_{2}$ 
5 доларів за тонну та акумуляції діоксиду вуглецю 0,56-2,15 т/рік становить в середньому 193,84 грн/га.
За результатами розрахунків, інтегральна вартісна оцінка екосистемних послуг Черемського болота склала 3696003 грн. (табл. 1).

Таблиия 1

\section{Інтегральна вартісна оцінка болотних екологічних систем перехідного болота Черемського природного заповідника}

\begin{tabular}{|c|c|}
\hline Площа ділянки, га & 1259,5 \\
\hline Загальний запас торфу, т & 3453297 \\
\hline Питомий запас торфу, т/га [1] & 2741,8 \\
\hline Показник поглинання діоксиду вуглецю, т/га (Ксо2) & 1,157 \\
\hline Коефіцієнт цінності водоочисної здатності $\left(K_{\phi}\right)$ & 0,411 \\
\hline $\begin{array}{l}\text { Коефріцієнт виходу продукції природокористування } 3 \\
\text { одиниці природної сировини (Квих) }\end{array}$ & 0,6 \\
\hline Кедля рідкіснихбіотопів & 2 \\
\hline $\begin{array}{l}\text { Капіталізатор, або коефріцієнт дисконтування, за ти- } \\
\text { пом екосистеми (qекl) }\end{array}$ & 0,001 \\
\hline Капіталізатор економічної ссрери $\left(q_{e}\right)$ & 0,05 \\
\hline $\begin{array}{l}\text { Ціна торфу фррезерного для сільського господарства, } \\
\text { грн/т }\end{array}$ & 200 \\
\hline Питома (щорічна) оцінка екологічної системи $\left(\mathrm{R}_{\mathrm{I}}\right)$ & 58,7 \\
\hline Поточна оцінка екосистемних послуг $\left(\mathrm{R}_{\mathrm{ek}}\right)$ & 2934,5 \\
\hline Інтегральна вартісна оцінка екосистемних послуг, грн & 3696003 \\
\hline
\end{tabular}

Варто зазначити, що поточна оцінка екосистемних послуг Черемського болота була розрахована за найменш ймовірними показниками (наприклад, вартість торфу 200 грн/т, балансовий річний стік $\mathrm{CO}_{2}$ для перехідного болота розрахували як 1,157 т/га, мінімальна пропускна здатність 411 м $^{3}$ за добу на га). Тому поточна оцінка перехідного болота сягає 2934,5 грн/рік, що становить 88 доларів за рік. За даними білоруських науковців, зокрема А. В. Неверова із співавт. [6], такий же показник для низинного болота становить 158 доларів, за даними Д. Г. Груммо із співавт. для верхового болота - близько однієї тисячі доларів [2].

Вартісна оцінка сорбційної (водоочисної) функції Черемського болота становить 345103 дол/рік або 11560951 грн/рік (табл. 2).

Таблиця 2

\section{Вартісна оцінка сорбційної функції Черемського болота}

\begin{tabular}{|c|c|}
\hline Площа, га & 1259,5 \\
\hline $\begin{array}{l}\text { річна приведена вартість промислової очисної устано- } \\
\text { вки, дол. }\end{array}$ & 1000 \\
\hline $\begin{array}{l}\Lambda_{\text {пром. }}-\text { фрільтруюча здатність промислової установки } \\
\text { м³/добу }\end{array}$ & 1500 \\
\hline 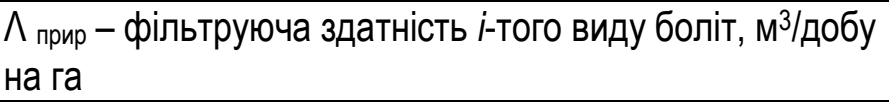 & 411 \\
\hline $\begin{array}{l}\text { Вартісна оцінка сорбційної (водоочисної) функції боліт, } \\
\text { дол/рік }\end{array}$ & 345103 \\
\hline
\end{tabular}

Для можливості порівняння вартості екосистемних послуг Черемського болота ми провели оцінку трьох ділянок сосни звичайної (табл. 3).
Перша ділянка - це деревостан сосни звичайної природного походження площею 7,4 га в кв.14, вид.32 Черемського природного 
заповідника. Склад насадження 10Сз+Бп, ॥ бонітет, вік 100 років, середня висота $-25,7$ м, середній діаметр - 31,4 см, повнота - 0,85, за-

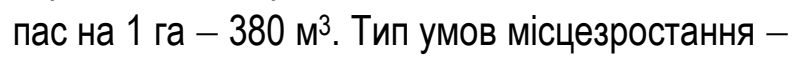
В3. Тип лісу - вологий дубово-сосновий субір (ДС).

Друга ділянка - насадження віком 107 років, площею 3,0 га, яке знаходиться в кв.11, вид.19. Склад насадження 10С, III бонітет, середня висота - 24,3 м, середній діаметр - 33,9 см, повнота $-0,90$, запас на 1 га $-390 \mathrm{~m}^{3}$. Тип умов місцезростання - $\mathrm{A}_{2}$. Тип лісу - свіжий сосновий бір (C).

Третя ділянка - деревостан віком 102 роки, площею 2,2 га, який знаходиться в кв.11, вид.15
Черемського природного заповідника. Склад насадження 10С+Бп, III бонітету. При середній висоті 20,2 м, середньому діаметрі 29,5 см та повноті 0,80 запас на 1 га становить $270 \mathrm{~m}^{3}$. Тип умов місцезростання - $\mathrm{A}_{1-2}$.

Для розрахунків поглинання діоксиду вуглецю сосняками ми використали мінімальне значення асиміляції $\mathrm{CO}_{2}-5$ тонн /га за рік.

Інтегральна вартісна оцінка екосистемних послуг лісових екосистем майже в тридцять разів вища, ніж болотної. Вартісна оцінка щорічного поглинання діоксиду вуглецю лісовими насадженнями також вища в чотири рази, порівняно з болотом.

Таблиця 3

\section{Результати розрахунків вартості екосистемних послуг Черемського болота}

\begin{tabular}{|l|c|c|c|c|c|}
\hline \multicolumn{1}{|c|}{ Тип екосистеми } & $\begin{array}{c}\text { Площа, } \\
\text { га }\end{array}$ & $\begin{array}{c}\text { Інтегральна } \\
\text { вартісна } \\
\text { оцінка } \\
\text { екосистемних } \\
\text { послуг, грн/рік }\end{array}$ & $\begin{array}{c}\text { Вартісна оцінка } \\
\text { щорічного } \\
\text { поглинання } \\
\text { діоксиду } \\
\text { вуглецю } \\
\text { екосистемами, } \\
\text { грн/рік }\end{array}$ & $\begin{array}{c}\text { Вартісна } \\
\text { оцінка } \\
\text { сорбційної } \\
\text { функції, } \\
\text { грн/рік }\end{array}$ & $\begin{array}{c}\text { Економічна } \\
\text { оцінка первинної } \\
\text { продукції } \\
\text { екосистеми, грн. }\end{array}$ \\
\hline Болото & 1259,5 & 3696003 & 244047,5 & 11560951 & 73932650 \\
\hline В розрахунку на 1 га & - & 2934,4 & 193,8 & 9179 & 58700 \\
\hline 10Сз+Бп,Вз & 7,4 & 701242,5 & 6197,5 & - & 17531062,5 \\
\hline В розрахунку на 1 га & - & 94762,5 & 837,5 & - & 2369062,5 \\
\hline 10Сз, А & 3,0 & 296540,7 & 2512,5 & - & 7294218,8 \\
\hline В розрахунку на 1 га & - & 98846,9 & 837,5 & - & 2431406,3 \\
\hline $\begin{array}{l}\text { 10Сз+Бп, } \\
\text { А1-2 }\end{array}$ & 2,2 & 148854,9 & 1842,5 & - & 3703218,8 \\
\hline В розрахунку на 1 га & - & 67661,3 & 837,5 & - & 1683281,3 \\
\hline
\end{tabular}

Ще одним методом, який дає змогу наближено визначити економічну оцінку ділянки лісу, $\epsilon$ сума рентної плати за заготівлю деревини під час проведення рубки головного користування.
Використовуючи дані закладених нами трьох пробних площ, отримали результати матеріально-грошової оцінки заготовленої деревини, які представлені в табл. 4-6. 
Матеріально-грошова оцінка заготовленої деревини при проведенні рубки головного користування у кв.14, вид.32, з розрахунку на 1 га

\begin{tabular}{|c|c|c|c|c|c|c|c|c|c|c|}
\hline \multirow{3}{*}{ 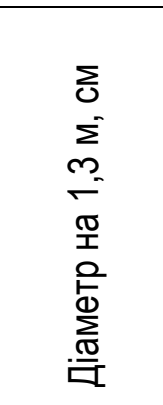 } & \multicolumn{10}{|c|}{ Порода Сосна Розряд масових таблиць $\underline{2}$} \\
\hline & \multicolumn{3}{|c|}{$\begin{array}{c}\text { Число } \\
\text { стовбурів }\end{array}$} & \multicolumn{4}{|c|}{ Ділова } & \multirow[b]{2}{*}{ 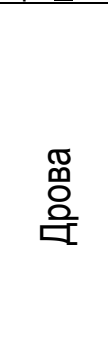 } & \multirow{2}{*}{ 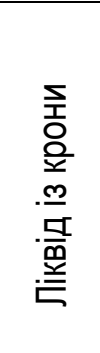 } & \multirow{2}{*}{ 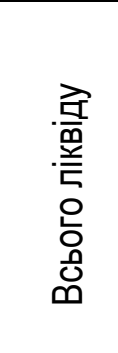 } \\
\hline & $\begin{array}{l}\text { 짐 } \\
\text { 음 } \\
\text { 음 }\end{array}$ & 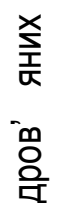 & $\begin{array}{l}\text { 응 } \\
\text { 요 }\end{array}$ & :울 & 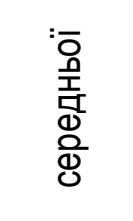 & $\begin{array}{l}: \overline{0} \\
\text { 옹 } \\
\text { 음 }\end{array}$ & $\begin{array}{l}\sum_{0} \\
\mathbb{\pi} \\
\mathbb{\Xi}\end{array}$ & & & \\
\hline 1 & 2 & 3 & 4 & 5 & 6 & 7 & 8 & 9 & 10 & 11 \\
\hline 12 & 1 & - & 1 & - & - & 0,07 & 0,07 & 0,004 & - & 0,074 \\
\hline 16 & - & - & - & - & - & - & - & - & - & - \\
\hline 20 & 8 & 1 & 9 & - & 1,52 & 0,48 & 2 & 0,38 & - & 2,38 \\
\hline 24 & $\begin{array}{l}2 \\
0\end{array}$ & 1 & 21 & - & 7 & 0,8 & 7,8 & 0,86 & 0,21 & 8,87 \\
\hline 28 & $\begin{array}{l}2 \\
4 \\
\end{array}$ & 2 & 26 & 1,2 & 12 & 0,48 & 13,68 & 1,82 & 0,26 & 15,76 \\
\hline 32 & $\begin{array}{l}1 \\
6 \\
\end{array}$ & 1 & 17 & 5,76 & 6,56 & - & 12,32 & 1,38 & 0,34 & 14,04 \\
\hline 36 & $\begin{array}{l}1 \\
4 \\
\end{array}$ & & 14 & 8,96 & 5,04 & - & 14 & 0,42 & 0,42 & 14,84 \\
\hline 40 & 6 & 1 & 7 & 5,64 & 1,92 & - & 7,56 & 1,7 & 0,28 & 9,54 \\
\hline 44 & 5 & & 5 & 6,3 & 1,45 & - & 7,75 & 0,25 & 0,25 & 8,25 \\
\hline Всього & $\begin{array}{l}9 \\
4\end{array}$ & 6 & 100 & 27,86 & 35,49 & 1,83 & 65,18 & 6,814 & 1,76 & 73,754 \\
\hline \multicolumn{4}{|c|}{ Всього ліквіду на 1 га } & 139 & 177 & 9 & 326 & 34 & 9 & 369 \\
\hline \multicolumn{4}{|c|}{ Ціна 1 м³, розряд такс 3} & 266,03 & 171,35 & 66,08 & - & 7,20 & 2,88 & - \\
\hline \multicolumn{4}{|c|}{ Сума в грн. } & 36978 & 30329 & 595 & 67902 & 245 & 26 & 68173 \\
\hline $\begin{array}{c}\text { Береза, } \\
\text { розряд } 4\end{array}$ & 9 & - & 9 & - & 1,38 & 0,24 & 1,62 & 0,42 & 0,06 & 2,1 \\
\hline \multicolumn{4}{|c|}{ Всього ліквіду на 1 га } & - & 7 & 1 & 8 & 2 & 0 & 11 \\
\hline \multicolumn{4}{|c|}{ Ціна 1 м³, розряд такс 3} & 38,03 & 33,98 & 25,79 & - & 8,99 & 3,60 & - \\
\hline \multicolumn{4}{|c|}{ Сума в грн. } & - & 238 & 26 & 264 & 18 & 0 & 282 \\
\hline \multicolumn{4}{|c|}{ Всього в грн. } & 36978 & 30567 & 621 & 68166 & 263 & 26 & 68455 \\
\hline
\end{tabular}


Матеріально-грошова оцінка заготовленої деревини при проведенні рубки головного користування кв. 11, вид. 19, з розрахунку на 1 га

\begin{tabular}{|c|c|c|c|c|c|c|c|c|c|c|}
\hline \multirow{3}{*}{ 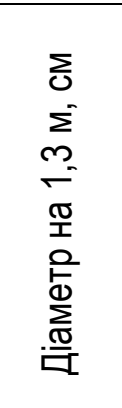 } & \multicolumn{10}{|c|}{ Порода Сосна Розряд масових таблиць $\underline{3}$} \\
\hline & \multicolumn{3}{|c|}{$\begin{array}{c}\text { Число } \\
\text { стовбурів }\end{array}$} & \multicolumn{4}{|c|}{ Ділова } & \multirow[b]{2}{*}{ 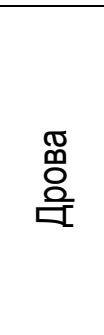 } & \multirow{2}{*}{ 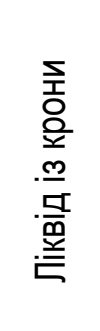 } & \multirow{2}{*}{ 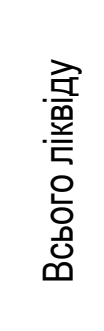 } \\
\hline & 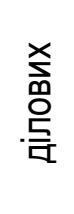 & 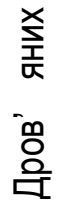 & $\begin{array}{l}\text { 은 } \\
\text { 욤 }\end{array}$ & $\begin{array}{l}: \overline{ } \\
\text { 졷 } \\
\text { 을 }\end{array}$ & 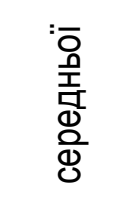 & $\begin{array}{l}: \overline{0} \\
\text { 옹 } \\
\text { 음 }\end{array}$ & 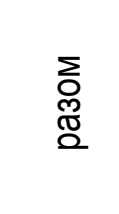 & & & \\
\hline 1 & 2 & 3 & 4 & 5 & 6 & 7 & 8 & 9 & 10 & 11 \\
\hline 20 & 3 & 1 & 4 & - & 0,48 & 0,21 & 0,69 & 0,31 & - & 1 \\
\hline 24 & 10 & 2 & 12 & - & 3,1 & 0,5 & 3,6 & 0,96 & 0,12 & 4,68 \\
\hline 28 & 21 & 1 & 22 & 0,84 & 9,66 & 0,42 & 10,92 & 1,03 & 0,22 & 12,17 \\
\hline 32 & 20 & & 20 & 6,4 & 7,8 & - & 14,2 & 0,6 & 0,4 & 15,2 \\
\hline 36 & 22 & 2 & 24 & 12,76 & 7,48 & - & 20,24 & 2,8 & 0,72 & 23,76 \\
\hline 40 & 9 & 1 & 10 & 7,56 & 2,79 & - & 10,35 & 1,7 & 0,4 & 12,45 \\
\hline 44 & 5 & - & 5 & 5,65 & 1,4 & - & 7,05 & 0,2 & 0,25 & 7,5 \\
\hline 48 & 3 & - & 3 & 4,32 & 0,78 & - & 5,1 & 0,15 & 0,21 & 5,46 \\
\hline $\begin{array}{l}\text { Всього } \\
\text { на ПП }\end{array}$ & 93 & 7 & 100 & 37,53 & 33,49 & 1,13 & 72,15 & 7,75 & 2,32 & 82,22 \\
\hline \multicolumn{4}{|c|}{ Всього ліквіду на 1 га } & 179 & 159 & 5 & 344 & 37 & 11 & 392 \\
\hline \multicolumn{4}{|c|}{ Ціна 1 м³, розряд такс 3} & 266,03 & 171,35 & 66,08 & - & 7,20 & 2,88 & - \\
\hline \multicolumn{4}{|c|}{ Сума в грн. } & 47619 & 27244 & 330 & 75193 & 266 & 32 & 75491 \\
\hline
\end{tabular}

Таблиия 6

Матеріально-грошова оцінка заготовленої деревини при проведенні рубки головного користування кв. 11, вид. 15, з розрахунку на 1 га

\begin{tabular}{|c|c|c|c|c|c|c|c|c|c|c|}
\hline \multirow{3}{*}{ 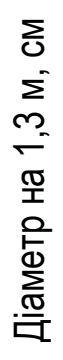 } & \multicolumn{10}{|c|}{ Порода Сосна Розряд масових таблиць $\underline{4}$} \\
\hline & \multicolumn{3}{|c|}{ Число стовбурів } & \multicolumn{4}{|c|}{ Ділова } & \multirow[b]{2}{*}{ 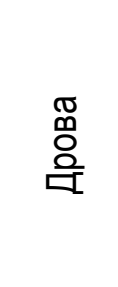 } & \multirow{2}{*}{ 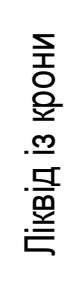 } & \multirow{2}{*}{ 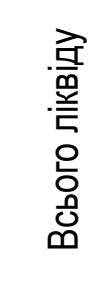 } \\
\hline & $\begin{array}{l}\stackrel{\times}{\mathfrak{心}} \\
\text { 高 }\end{array}$ & 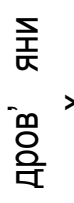 & 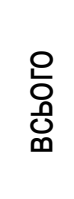 & $\begin{array}{l}: \overline{0} \\
\text { 올 } \\
\text { 을 }\end{array}$ & 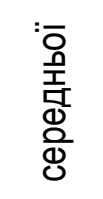 & $\begin{array}{l}: \overline{0} \\
\text { 옹 } \\
\text { 음 }\end{array}$ & 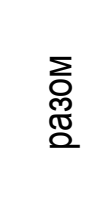 & & & \\
\hline 1 & 2 & 3 & 4 & 5 & 6 & 7 & 8 & 9 & 10 & 11 \\
\hline 12 & 1 & - & 1 & - & & 0,059 & 0,059 & 0,003 & - & 0,062 \\
\hline 16 & 12 & - & 12 & - & 0,36 & 1,08 & 1,44 & 0,12 & - & 1,56 \\
\hline 20 & 12 & - & 12 & - & 1,56 & 0,96 & 2,52 & 0,12 & - & 2,64 \\
\hline
\end{tabular}


Закінчення таблиці 6

\begin{tabular}{|c|c|c|c|c|c|c|c|c|c|c|}
\hline 1 & 2 & 3 & 4 & 5 & 6 & 7 & 8 & 9 & 10 & 11 \\
\hline 24 & 19 & - & 19 & - & 5,13 & 1,14 & 6,27 & 0,19 & 0,19 & 6,65 \\
\hline 28 & 16 & 1 & 17 & 0,48 & 6,72 & 0,32 & 7,52 & 0,88 & 0,17 & 8,57 \\
\hline 32 & 14 & - & 14 & 3,92 & 5,04 & - & 8,96 & 0,28 & 0,28 & 9,52 \\
\hline 36 & 12 & - & 12 & 6,12 & 3,84 & - & 9,96 & 0,36 & 0,36 & 10,68 \\
\hline 40 & 10 & - & 10 & 7,5 & 2,9 & - & 10,4 & 0,3 & 0,4 & 11,1 \\
\hline 44 & 2 & - & 2 & 2 & 0,56 & - & 2,56 & 0,08 & 0,12 & 2,76 \\
\hline 48 & & - & - & - & - & - & - & - & - & - \\
\hline 52 & 1 & - & 1 & 1,58 & 0,25 & - & 1,83 & 0,06 & 0,1 & 1,99 \\
\hline $\begin{array}{c}\text { Всього на } \\
П П \\
\end{array}$ & 99 & 1 & 100 & 21,6 & 26,36 & 3,559 & 51,519 & 2,393 & 1,62 & 55,532 \\
\hline \multicolumn{4}{|c|}{ Всього ліквіду на 1 га } & 103 & 126 & 17 & 245 & 11 & 8 & 264 \\
\hline \multicolumn{4}{|c|}{ Ціна 1 м³, розряд такс 3} & 266,03 & 171,35 & 66,08 & - & 7,20 & 2,88 & - \\
\hline \multicolumn{4}{|c|}{ Сума в грн. } & 27401 & 21590 & 1123 & 50114 & 79 & 23 & 50216 \\
\hline $\begin{array}{c}\text { Бп, } \\
\text { розряд } 4\end{array}$ & 6 & & 6 & - & 0,96 & 0,15 & 1,11 & 0,3 & 0,03 & 1,44 \\
\hline \multicolumn{4}{|c|}{ Всього ліквіду на 1 га } & - & 4 & 1 & 4 & 1 & 0 & 6 \\
\hline \multicolumn{4}{|c|}{ Ціна 1 м³, розряд такс 3} & 38,03 & 33,98 & 25,79 & - & 8,99 & 3,60 & - \\
\hline \multicolumn{4}{|c|}{ Сума в грн. } & - & 136 & 26 & 162 & 9 & - & 171 \\
\hline \multicolumn{4}{|c|}{ Всього в грн. } & 27401 & 21726 & 1149 & 50276 & 88 & 23 & 50387 \\
\hline
\end{tabular}

Сума рентної плати за заготівлю деревини з першої ділянки становитиме 68455 грн 31 га, 3 другої - 75491 грн з 1 га., третьої 50387 грн 3 1 га.

Як і варто було очікувати, інтегральна вартісна оцінка екосистемних послуг лісових екосистем дещо вища (на 26\%) за матеріально-грошову оцінку заготовленої деревини при проведенні рубки головного користування.

Проведення природоохоронних робіт на території Черемського болота забезпечить виконання екосистемних послуг перехідним болотом на суму 3696003 грн/рік, а також збереження сорбційної (водоочисної) функції болота на суму 11560951 грн/рік, і поглинання діоксиду вуглецю на суму 244048 грн/рік.

\section{ВИСНОВКИ}

Апробація економічної оцінки Черемського болота на основі екосистемних послуг показала, що щорічний економічний ефект від збереження екосистеми Черемського болота тільки за мінімальними оцінками (інтегральною оцінкою екосистемних послуг) складає 3696003 грн/рік, а 3 урахуванням коефіцієнта капіталізації 0,001 110 млн. дол., що в 5,4 раза перевищує вартість торфовищ. Проте екосистемні послуги болотної екосистеми поступаються вартості послуг лісових екосистем.

\section{ЛITEPATУРA}

1. Веремеєнко, С. І.; Стріха, В. А. Перспективи використання торфу для відтворення родючості ґрунтів. Вісник ЖНАЕУ 2017, 1 (58), Т. 1 , c 21-29.

2. Груммо, Д. Г.; Зеленкевич, Н. А.; Созинов, О. В.; Мойсейчик, Е. В. Эколого-экономическая оценка экосистемных услуг при оптимизации гидрологического режима верхового болота Ельня (Беларусь). Вестник МПГУ 2016, 1, c 57-66. 
3. Економічна енциклопедія. у 3-охт. Академія: Київ, 2000, Т. 1, с 432-433.

4. Лицур, І. М. Методичні підходи до економічної оцінки лісових ресурсів. Економіка природокористування і охорони довкілля: зб. наук. праць. ДУ ІЕПСР НАН України: Київ, 2012, c 49-56.

5. Неверов, А. В.; Варапаева, О. А. Стоимостная оценка экосистемных услуг и биологического разнообразия. Труды БГТУ 2013, 17, Экономика и управление; с 95-100.

6. Неверов, А. В.; Редковская, Д. А.; Неверов, Д. А. Экономическая оценка биоразнообразия особоохраняемых природных территорий Беларуси. Природные ресурсы 2001, 3, 89 с.

7. Проект організації території Черемського природного заповідника та охорони його природних комплексів / Карпа, М. А.; Громов, Є. М.; Піпа, Р. С.; Вірченко, В. М.; Зеленко, С. Д.; Коніщук, В. В.; Коновальчук, В. К.; Мазяр, В. П.; Парчук, Г. В.; Пащук, С. І.; Петльований, О. А.; Придюк, М. П.; Химин, М. В.; Царенко, П. М.; Шевчук, Л. О. Львівська лісовпорядна експедиція: Львів, 2005; 320 с.
8. Савчук, П. Охорона боліт. Досвід Європи та Білорусі. Уроки та рекомендації для України. [Електронний ресурс]. Сайт Екологія. Право. Людина. URL: http://epl.org.ua/announces/ohoronabolit-dosvid-yevropy-ta-bilorusi-uroky-tarekomendatsiyi-dlya-ukrayiny/.

9. Стратегія реформування лісового господарства. [Електронний ресурс]. Сайт Житомирського обласного управління лісового і мислисливського господарства. URL: https://ztlis.gov.ua/fileadmin/user

upload/\%D0\%BC\%D0\%B5\%D0\%B4\%D1\%96\%D0 \%B0/\%D0\%BF\%D1\%80\%D0\%B5\%D0\%B7\%D0\% B5\%D0\%BD\%D1\%82\%D0\%B0\%D1\%86\%D1\%96 \%D1\%97/\%D0\%A0\%D0\%B5\%D1\%84\%D0\%BE\% D1\%80\%D0\%BC\%D1\%83\%D0\%B2\%D0\%B0\%D0 \%BD\%D0\%BD\%D1\%8F \%D0\%B3\%D0\%B0\%D0 \%BB\%D1\%83\%D0\%B7\%D1\%96.pdf.

10. Шимова, О. С.; Лопачук, О. Н.; Байчоров, В. М. Экономическая эфффективность мероприятий по сохранению биологического разнообразия. Беларус. навука: Минск, 2010; 123 с. 